\title{
5 Broadleaf Weed Control with Some Recent Post-emergence Herbicides in Bread Wheat (Triticum aestivum L.) in Egypt
}

\author{
S. A. Safina and R. Absy \\ Agronomy Department, Faculty of Agriculture, Cairo University, Cairo, Egypt.
}

Received: $14 / 1 / 2017$

Accepted: 23/3/2017

\begin{abstract}
ROADLEAF weeds cause severe competition with wheat crop in Egypt and its highly reduce yield. Two field experiments during two winter seasons were conducted in the Experimental Research Station of the Faculty of Agriculture, Cairo University, Giza Governorate, Egypt during winter seasons of 2014/2015 and 2015/2016. The aim of this work was to control broadleaf weeds in wheat and evaluate of 17 broadleaf weed herbicides in wheat (Triticum aestivum L.) CV. Gemeza- 11. Weed control treatments were hand pulling and applying 17 experimental post-emergence herbicides, were applied bromoxynil-octaneoate $24 \%$, DICAMBA 48\%, Tribenuron-Methyl $16 \%$ + Carfentrazone-Ethyl $12 \%$, MCPA-sodium 20\%+Bromixanil $20 \%$, Florasulam $0.25 \%+$ MesosulfuronMethyl $0.75 \%$, MCPA-sodium 36\%+ Florasulam 1\% , Florasulam $05 \%+$ Clodinafop-propagyl $6.5 \%$, Tribenuron-Methyl $2.7 \%+$ Fluroxypyr $13.7 \%$, Tribenuron-Methyl 5\%+ Clodinafop-propagyl 10\%, bromoxynil-octanoate $25 \%$, Triasulfuron 4.1\% + Dicamba $65.9 \%$, Tribenuron-Methyl 8\%+ Fenoxaprop-pEthyl45\%+ Thifensulfuron-Methyl 12\%, Bromoxynil octaneoate, Florasulam $1.42 \%+$ Pyroxsulam $7.08 \%$,Florasulam $1.42 \%+$ Pyroxsulam $7.08 \%+$ Ecosurf, Tribenuron-Methyl and Fluroxypyr 10\% + Florasulam .025\% + Clopyralid 8\%. Application of herbicides was after 25 days from sowing date in both seasons, and hand pulling twice after 25 and 45 days. Presented data showed that all weed control treatments (herbicides and hand weeding twice) reduced broadleaved weed density and weight. These treatments, increased wheat yield and yield components significantly compared to weedy check, except Florasulam $1.42 \%+$ Pyroxsulam $7.08 \%$, which recorded reduction in wheat yield. Triasulfuron $4.1 \%+$ Dicamba $65.9 \%$, gave the highest number of grains/ spikelet and spike per plant and straw yield $\mathrm{t} / \mathrm{ha}$, and the best treatment in grain yield was Tribenuron-Methyl $2.7 \%+$ Fluroxypyr $13.7 \%$ herbicide compared with weedy check..
\end{abstract}

Keywords: Wheat (Triticum aestivum), Broadloeaf weeds, Post-emergence herbicides.

\section{INTRODUCTION}

Wheat (Triticum aestivum L.) is the most important cereal crop in Egypt and in the world, since it is stable food for humans. Wheat grains, in Egypt represents almost 10 percent of the total value of agricultural production and about 20 percent of all agricultural imports. (Egypt wheat Sector Review, FAO, 2016)

Wheat is very improtant ceral crops was supplies more than $70 \%$ of the calories and protein. wheat is annual winter crop, belongs to family Greamineae, self pollinated and photo periodically long day plant. There is a gap between the local wheat production and the pepole consumption, so, it is very important to investigate the optimum crop practices, such as weed management, fertilization and sowing methods, ...etc. to increase wheat grain production.

Weeds are define as undesirable plants and infest most crops and reduce crop yields. There are many reports on the inhibitory effects of weeds on crop yields (Javaid et al., 2007).Weeds are consider the important factor which adversely reduce yield of wheat. Weeds compete with crop plants for the important crop growth requirements and reduce quality and yields of the crop, also increase the cost for harvesting and cleaning. Weed management is very important component of management practices recommended to increase crop production. Herbicides are most important tools for weed management to improve yield and quality. Chemical weed control is quick, more effective and cheaper so it is promote over other weed control methods. 
Various investigators have evaluated the efficacy of different herbicides for control of weeds in wheat crop. Ali \& Shams El-Din (1997) recorded that the yield and yield attributes of wheat were higher under bromoxynil-actanoate [Brominal] application at rate $2.38 \mathrm{~L} /$ ha than hand weeding twice. Hassanein et al. (2000) stated that wheat yield losses due to weed competition were amounted to $20 \%$. The loss in wheat yield at 50 weeds $/ \mathrm{m}^{2}$ was $19 \%$, and at 100 weeds $/ \mathrm{m}^{2}$ the loss was $38.8 \%$. Jitendra et al. (2002) showed that the weed resulted in significant decrease in wheat plant height, productive tillers $/ \mathrm{m}^{2}$, grains / spike and 1000 grain weight as well as reduction in crop yield by $27.2 \%$.

Shah et al. (2004) found that Isoproturon gave the highest wheat yield. Malik et al. (2004) indicated that the maximum number of spikes $/ \mathrm{m}^{2}$ and wheat yield were achieved by using Diclofopmethyl at $700 \mathrm{~g}$ ha, after first irrigation. Zand et al. (2007) reported that weeds infestation caused $30 \%$ grain yield losses of wheat. Khan et al. (2008) recorded that the maximum number of tillers, weight of 1000-grain, biological and grain yield by Isoproturon $50 \% \mathrm{WP} 1 \mathrm{~kg} / \mathrm{ha}$ followed by Buctril super $60 \%$ EC at $045 \mathrm{~kg} / \mathrm{ha}$ as compared to the weedy check, respectively.

Hossain et al. (2009) stated that weed dry weights and numbers were low by Affinity @ 1.5 $\mathrm{kg} / \mathrm{ha}$ after 25 DAS (days after sowing) compared with control tretment. Affinity @1.5 kg/ha after 25 DAS showed high efficiency of weed control $(77.4 \%)$ compared with hand pulling $(78.2 \%)$. The optimum wheat grain yield (4.28 t/ha) was obtained by Affinity@1.5 kg/ha after 25 DAS and hand pulling (4.35t/ha), higher absorption of nutrients and sufficient interception of sunlight as well as air circulation, might be due to less weed-wheat competition resulting in higher grain yield .Increase of weed populations gradually decreased wheat yield. Shahram et al. (2011) indicated that increase wild oat (Avena fatua) density had a significant effect on wheat grain yield. Reductions in wheat grain yield 25, 50 and 75 wild oat plants $/ \mathrm{m}^{2}$ were about $12 \%, 25.7 \%$ and $35.4 \%$, respectively compared to the weedy check treatment. Muhammad et al. (2012) revealed that post-emergence herbicides application of Isoproturon (1080 $\mathrm{g}$ a.i ha) proved to, the best for obtaining maximum wheat grain and straw yield.

Khalil et al. (2013) stated that in weedy check were recorded maximum number of weeds 117 weeds $\mathrm{m}^{2}$. Similarly the high grain yield $4.072 \mathrm{t}$ ha was recorded by affinity herbicides followed by hand pulling of Buctril Super + Puma Super with grain yield $3.773 \mathrm{t} / \mathrm{ha}$ and $3.483 \mathrm{t} / \mathrm{ha}$, respectively. While the lowest grain yield of 1.603 $\mathrm{t} /$ ha was recorded in weedy check treatments. Application of affinity herbicides also proved to be effective in other wheat yield components like spikes $\mathrm{m}^{-2}$, number of grains spike ${ }^{-1}$ and 1000 grain weight. Tesfay et al. (2014) reported that hand pulling followed by Isoproturon herbicides at $1.50 \mathrm{~kg} / \mathrm{ha}$ significantly reduced weed densites and dry weights. Among herbicides, Isoproturon provided the best broadleaved weed control and total weeds, as well as; Clodinafop- propargyl in controlling grass weeds species. Hand pulling and hoeing at tillering resulted in lowest weed dry weights. The high grain yield $(2289.4 \mathrm{~kg} / \mathrm{ha})$ was recorded by hand pulling followed by Isoproturon at $1.5 \mathrm{~kg}$ ha The highest straw yield was recorded in hand pulling followed by Isoproturon 1.50 $\mathrm{kg} / \mathrm{ha}$, and harvest index was also maximum with hand pulling. Post emergence herbicides, hoeing and hand pulling at tillering can further enhance the weed suppressive effect of the wheat crop. Raza et al. (2015) reported that wheat grain yield was achieved with Buctril Super $750 \mathrm{ml} /$ ha was application.

Under the changing of socio-economic conditions, availability of the agricultural labors is reducing day by day that hampered agricultural operations seriously. Grain yield of wheat can be increased through proper weed management. Application of herbicides may be an effective and alternative option for proper weed management to boost up the wheat grain yield. Under this circumstance, this work was designed to study the activity of 17 post-emergence herbicides in controlling wheat associated weeds and enhancing yield and its components.

\section{MATERIALS AND METHODS}

Two field experiments were conducted during the two successive growing winter seasons 2014/15 and 2015/16 at the Experimental Station of the Faculty of Agriculture, Cairo University, Giza Governorate, Egypt. Each field experiment included: 19 weed control treatments as follows 17 post-emergence herbicides shown in Table 1, hand pulling twice and untreated plots check weed control treatment.

The treatments were arranged in a randomized complete blocks design with four replicates in both seasons. The plot area was $10.5 \mathrm{~m}^{2}$ (3.5 m length 
and $3.0 \mathrm{~m}$ width). Each plot included 15 rows. Wheat (Triticum aestivum L.) cultivar Gemeza-11 was sown by drill sowing method on $20^{\text {th }}$ and $25^{\text {th }}$ November in both seasons. Herbicides were applied post emergence after four weeks from sowing. A knapsack sprayer equipped with one nozzle boom was used and the water volume was $476 \mathrm{~L} / \mathrm{ha}$. All agricultural practices i.e. fertilizer, irrigation, pest and disease control were carried out according to the local recommendations. The soil texture of the experimental field was clay loam in both seasons. Harvest was done on $15^{\text {th }}$ and $30^{\text {th }}$ May in both seasons, respectively.

Data recorded: During the growing seasons, the following data were recorded:

Weed survey was carried out at 60 Days after sowing. Weeds were hand pulled from one square meter of each plot. Samples of weeds were identified according to Tackholm (1974) and classified into the following group annual broad - leaved weeds. The fresh weight and number of annual broad - leaved weeds was estimated. Weed control efficiency (WCE) was calculated as follows:

$$
\mathrm{WCE} \%=\{(\mathrm{FWC}-\mathrm{FWT}) \div \mathrm{FWC}\} \times 100
$$

where, $\mathrm{FWC}=$ Fresh weight of weeds in unweeded or checky treatment and FWT $=$ Fresh weight of weeds in weed control.

Yield and its components: number of spikes $/ \mathrm{m}^{2}$; number of spikes per square meter was measured before harvest as the number of spikes per one square meter chosen randomly from each plot. At harvest, ten wheat plants chosen randomly

TABLE 1. Herbicide trade names, common names, chemical names, rate/ha, and time of application from sowing date.

\begin{tabular}{|c|c|c|c|c|}
\hline Trade names & Rate /ha. & & Common name & Time \\
\hline Brominal $24 \%$ & $2.38 \mathrm{~L}$ & $\mathrm{EC}$ & Bromoxynil-octaneoate & 25 \\
\hline Dimo Up 48\% & $595 \mathrm{~cm}^{3}$ & SL & DICAMBA & 25 \\
\hline Gastin 28\% & $83.3 \mathrm{~g}$ & WP & $\begin{array}{l}\text { Tribenuron-Methyl } 16 \%+ \\
\text { Carfentrazone-Ethyl 12\% }\end{array}$ & 25 \\
\hline Rondu $40 \%$ & $1428 \mathrm{~g}$ & SP & $\begin{array}{l}\text { MCPA-sodium } \\
20 \%+\text { Bromixanil } 20 \%\end{array}$ & 25 \\
\hline Dolphic 1\% & $1785 \mathrm{~cm}^{3}$ & OD & $\begin{array}{l}\text { Florasulam } 0.25 \%+ \\
\text { Mesosulfuron-Methyl } 0.75 \%\end{array}$ & 25 \\
\hline Trigos 36\% & $595 \mathrm{~cm}^{3}$ & OD & $\begin{array}{l}\text { MCPA-sodium } 36 \%+ \\
\text { Florasulam } 1 \%\end{array}$ & 25 \\
\hline Arina $7 \%$ & $1198 \mathrm{~cm}^{3}$ & OD & $\begin{array}{l}\text { Florasulam } 05 \%+\text { Clodinafop- } \\
\text { propagyl } 6.5 \%\end{array}$ & 25 \\
\hline Aldol 20\% & $285.6 \mathrm{~g}$ & WP & $\begin{array}{l}\text { Tribenuron-Methyl } 2.7 \%+ \\
\text { Fluroxypyr } 13.7 \%\end{array}$ & 20 \\
\hline Patchi 15\% & $476 \mathrm{~g}$ & WP & $\begin{array}{l}\text { Tribenuron-Methyl } 5 \%+ \\
\text { Clodinafop-propagyl } 10 \%\end{array}$ & 20 \\
\hline Rabido $25 \%$ & $2.38 \mathrm{~L}$ & $\mathrm{EC}$ & bromoxynil-octanoate & 25 \\
\hline Lintor $70 \%$ & $142.8 \mathrm{~g}$ & WG & $\begin{array}{l}\text { Triasulfuron } 4.1 \% \text { +Dicamba } \\
65.9 \%\end{array}$ & 20 \\
\hline Moar 55\% & $238 \mathrm{~g}$ & WP & $\begin{array}{l}\text { Tribenuron-Methyl } 8 \%+ \\
\text { Fenoxaprop-p-Ethyl } 45 \%+ \\
\text { Thifensulfuron-Methyl } 12 \%\end{array}$ & 25 \\
\hline Bromoplus 24\% & $2.38 \mathrm{~L}$ & $\mathrm{EC}$ & Bromoxyniloctaneoate & 25 \\
\hline Braod way star $8.5 \%$ & $90 \mathrm{~cm} 3$ & WG & $\begin{array}{l}\text { Florasulam } 1.42 \%+ \\
\text { Pyroxsulam } 7.08 \%\end{array}$ & 25 \\
\hline $\begin{array}{l}\text { Braod way star } 8.5 \%+ \\
\text { Adjuvant }\end{array}$ & $\begin{array}{l}214.2 \mathrm{~cm}^{3}+ \\
476 \mathrm{~cm}^{3}\end{array}$ & WG & $\begin{array}{l}\text { Florasulam } 1.42 \%+ \\
\text { Pyroxsulam } 7.08 \%+\text { Ecosurf }\end{array}$ & 25 \\
\hline Kash cool 75\% & $19.04 \mathrm{~g}$ & WG & Tribenuron-Methyl & 25 \\
\hline Floromix $18.25 \%$ & $1547 \mathrm{~g}$ & $\mathrm{EC}$ & $\begin{array}{l}\text { Fluroxypyr } 10 \%+\text { Florasulam } \\
.025 \%+\text { Clopyralid } 8 \%\end{array}$ & 25 \\
\hline
\end{tabular}

$\mathrm{EC}=$ Emulsifiable Concentrate, $\mathrm{SL}=$ Soluble concentrate, $\mathrm{WP}=$ Wettablepowder, $\mathrm{WG}=$ Water dispersible granules, $\mathrm{OD}=$ Dusts. 
from the central rows of each plot was taken to determine the following characteristics: plant height $(\mathrm{cm})$; number of spikeletes/spike, number of grains/spikelet's number of grains/spike, grain weight/spike (g) and 1000- grain weight (seed index). The grains weight/spike (g) was calculated as an average of ten main spikes chosen randomly.

Grain yield was recorded as $\mathrm{t} / \mathrm{ha}$ from the whole area for each plot, Straw yield (t/ha) was determined by weighing the biological yield in each plot then substrating the grain weight for the biological yield. Expressed as t/ha. Harvest index (HI) was calculated by using following formula: HI $(\%)=($ Grain yield $/$ ha $\div$ Biological yield/ha $)$ $\times 100$.

\section{Statistical analysis}

Collected data were statistically analyzed using MSTAT-C computer package program and mean differences among treatments were evaluated by Least Significance Difference (LSD) test at 5\% level of significance (Gomez \& Gomez, 1984).

\section{RESULTS AND DISCUSSION}

Weed flora distribution at the experimental site

Scientific, common and local names of dominant weed species associated with wheat at the experimental site through 2014/2015 and 2015/2016 seasons were listed in Table 2 according to the composite list of weeds by Weed Sci. Soc. of Am. online http://wssa.net/wssa/ weed/weed-identification/ and also weed were identified according to Tackholm (1974).

\section{Weed growth characters}

Weed count $/ \mathrm{m}^{2}$, fresh weigh $/ \mathrm{m}^{2}$ and percent of weed control are important parameters for studying weed management methods. Weed growth characters regarding weed control treatments presented in Table 3 showed that all broadleaf weeds post-emergence herbicides significantly reduced number of broadleaf weeds per $\mathrm{m}^{2}$ and fresh weight/ $\mathrm{m}^{2}$ compared to weedy check (unweeded control).

However, the minimum weed count $/ \mathrm{m}^{2}$ was recorded with Rowndo and Dolphik at 15 weed plants $/ \mathrm{m}^{2}$ followed in the second rank by Trigous, Cash cool, Arina and Patchi. The highest weed control percent (more than $90 \%$ ) was recorded with the nine herbicides Rowndo, Dolphic, Trigous, Arina, Rapido, Gastin, Florumix, Cash cool and Broad way star with adjuvant. These treatments decreased the fresh weight $/ \mathrm{m}^{2}$ of broad leaved weeds, respectively. These outcomes are in conformity with those acquired by Shaban \& ElDeek (1986), Fayed et al. (1993), Barhoma et al. (1996), Atalla (1998), Hossain et al. (2009) and Tesfay et al. (2014).

\section{Wheat yield components}

Different weed control treatments showed a significant effect on plant height, number of spikes $/ \mathrm{m}^{2}$, grain weight/spikelet and grain weight/ spike (Table 4). Data arranged in Table 4 showed that plant height differed significantly among various weed control treatments. In addition, many weed control treatments increased plant height significantly, as Rapido (107 cm), Dolphik equal Dimo up $(105 \mathrm{~cm})$, Boradway star + Adjuvant $(103 \mathrm{~cm})$ and Hand pulling $(103 \mathrm{~cm})$. Such findings perhaps due to the role of efficacy of treatments of weed control in controlling weeds, which resulted in decreasing weedwheat competition on light and there factors of the environmental conditions. These outcomes are not in alignment with the previous findings of Muhammad et al. (2012) who found that the highest plant height $(98.30 \mathrm{~cm})$ was acquired from weedy check, while the minimum plant height $(88.60 \mathrm{~cm})$ was attained with Isoproturon + Diflufenican (1080 g a.i /ha). Khalil et al. (2000) and Marwat et al. (2005) declared that there was no significant increase in the plant height with the application of herbicides.

All the herbicides used has significantly influenced on number of spikes $/ \mathrm{m}^{2}$. The maximum number of spikes $/ \mathrm{m}^{2}$ (578) was obtained with the application of Aldoal, as well as, hand pulling (547), Rowndo (524) and Bromoplus (507) (Table 4). While, the minimum number of spikes/ $\mathrm{m}^{2}$ was recorded with Broad way star plus adjuvant (352) and weedy check 414 spikes $/ \mathrm{m}^{2}$. Herbicides Aldoal, Rowndo and Bromoplus performed the superior in order to efficient weed control, lower fresh weight of weeds, which resulted in minimum competition. These results are in harmony with Fenni et al. (2002).

In addition, grain weight/spikelet and spike was significantly affected by weed control treatments presented in Table 4. All control treatments of broadleaved weeds increased grain weight/spikelet and spike and all treatments had exhibited a significant effect compared to weedy check treatment. The maximum grain weight per 
TABLE 2. Dominant annual broadleaf weed species in wheat trials during 2014/2015 and 2015/2016 winter seasons.

\begin{tabular}{|l|l|l|l|}
\hline Scientific name & English name & Local name & Family \\
\hline Ammi majus L. & Common bishop & Khela & Umbelliferae \\
\hline Anagillus arvensis L & Scarlet Pimpernel & Ain El-gamal & Primulaceae \\
\hline Beta vulgaris L. & Sea beet & Salk & Chenopodiaceae \\
\hline Brassica nigra L. & Mustrad & Kaber & Cruciferae \\
\hline Medicago polymorpha L. & Toothed medik & Nafal & Fabaceae \\
\hline Rumex dentatus L. & Sheep sorrel & Hommeid & Polygonaceae \\
\hline Sonchus oleraceus L. & Annual sowthistle & Godeid & Asteraceae \\
\hline Malva parviflor & Cheeseweed mallow & Khobiza & Malvaceae \\
\hline
\end{tabular}

TABLE 3. Number of weeds $/ \mathrm{m}^{2}$, fresh weight after 20 days of herbicides application and weed control efficacy \% in combined data across seasons.

\begin{tabular}{|c|c|c|c|c|}
\hline Treatments & Rate / ha & No. of weeds $/ \mathbf{m}^{2}$ & Fresh weight $\left(\mathrm{g} / \mathrm{m}^{2}\right)$ & Control efficiency \% \\
\hline Brominal & $2.38 \mathrm{~L}$ & 32 & 136 & 85 \\
\hline Kash cool & $19.04 \mathrm{~g}$ & 18 & 63 & 93 \\
\hline Broad w. s .+ Adj. & $214.2 \mathrm{~g}+476 \mathrm{~cm}$ & 21 & 68 & 92 \\
\hline Broad way star & $214.2 \mathrm{~g}$ & 23 & 87 & 90 \\
\hline Bromoplus & $2.38 \mathrm{~L}$ & 30 & 100 & 89 \\
\hline Moar & $238 \mathrm{~g}$ & 26 & 117 & 87 \\
\hline Dimo up & $595 \mathrm{~cm} 3$ & 41 & 110 & 88 \\
\hline Gastin & $83.2 \mathrm{~g}$ & 20 & 53 & 94 \\
\hline Rondu & $1428 \mathrm{~g}$ & 15 & 47 & 95 \\
\hline Dolphic & $1785 \mathrm{~cm} 3$ & 15 & 40 & 95 \\
\hline Trigos & $595 \mathrm{~cm} 3$ & 17 & 40 & 95 \\
\hline Arina & $1190 \mathrm{~cm} 3$ & 18 & 39 & 95 \\
\hline Aldol & $285.6 \mathrm{~g}$ & 21 & 99 & 89 \\
\hline Patchi & $200 \mathrm{~g}$ & 42 & 95 & 90 \\
\hline Rabido & $2.38 \mathrm{~L}$ & 19 & 43 & 95 \\
\hline Floromix & $1547 \mathrm{~cm} 3$ & 20 & 48 & 94 \\
\hline Lintor & $142.8 \mathrm{~g}$ & 29 & 128 & 86 \\
\hline Hand pulling & & 35 & 171 & 82 \\
\hline Untreated (control) & & 111 & 963 & \\
\hline $\mathrm{LSD}_{0.05}$ & & 4.5 & 74.6 & \\
\hline CV \% & & 13.52 & 15.40 & \\
\hline
\end{tabular}


TABLE 4. Plant height $(\mathrm{cm})$, number of spikes $/ \mathrm{m}^{2}$, grain weight/spikelet and grain weight/spike as affected by weed control treatments for combined data across seasons.

\begin{tabular}{|c|c|c|c|c|c|}
\hline Treatments & Rate / ha & $\begin{array}{c}\text { Plant } \\
\text { height, }(\mathrm{cm})\end{array}$ & $\begin{array}{c}\text { No. of } \\
\text { spikes } / \mathbf{m}^{2}\end{array}$ & $\begin{array}{c}\text { Grain weight/ } \\
\text { Spike (g) }\end{array}$ & $\begin{array}{l}\text { Grain weight/ } \\
\text { Spikelet (mg) }\end{array}$ \\
\hline Brominal & $2.38 \mathrm{~L}$ & 102 & 473 & 3.05 & 129.9 \\
\hline Kash cool & $19.04 \mathrm{~g}$ & 99 & 468 & 2.99 & 134.8 \\
\hline Broad way star + Adjuvant & $214.2 \mathrm{~g}+476 \mathrm{~cm}^{3}$ & 103 & 352 & 3.10 & 136.1 \\
\hline Broad way star & $214.2 \mathrm{~g}$ & 97 & 372 & 3.23 & 146.4 \\
\hline Bromoplus & $2.38 \mathrm{~L}$ & 100 & 507 & 3.09 & 150.4 \\
\hline Moar & $238 \mathrm{~g}$ & 103 & 362 & 3.07 & 140.8 \\
\hline Dimo up & $595 \mathrm{~cm}^{3}$ & 100 & 426 & 3.18 & 143.2 \\
\hline Gastin & $83.2 \mathrm{~g}$ & 105 & 451 & 2.92 & 140.3 \\
\hline Rondu & $1428 \mathrm{~g}$ & 102 & 524 & 3.35 & 141.2 \\
\hline Dolphic & $1785 \mathrm{~cm}^{3}$ & 105 & 484 & 3.12 & 146.6 \\
\hline Trigos & $595 \mathrm{~cm}^{3}$ & 98 & 403 & 2.53 & 112.7 \\
\hline Arina & $1190 \mathrm{~cm}^{3}$ & 96 & 469 & 2.87 & 126.2 \\
\hline Aldol & $285.6 \mathrm{~g}$ & 105 & 578 & 2.79 & 123.3 \\
\hline Patchi & $200 \mathrm{~g}$ & 102 & 464 & 3.01 & 140.5 \\
\hline Rabido & $2.38 \mathrm{~L}$ & 102 & 451 & 2.86 & 126.4 \\
\hline Floromix & $1547 \mathrm{~cm}^{3}$ & 107 & 518 & 2.68 & 125.5 \\
\hline Lintor & $142.8 \mathrm{~g}$ & 103 & 424 & 3.33 & 146.4 \\
\hline Hand weeding twice & - & 103 & 547 & 2.69 & 123.3 \\
\hline Untreated & - & 94 & 414 & 1.74 & 95.0 \\
\hline $\mathrm{LSD}_{0.05}$ & $=$ & 4.5 & 41.1 & 0.29 & 14.5 \\
\hline CV \% & - & 3.82 & 7.80 & 8.50 & 9.44 \\
\hline
\end{tabular}

$\mathrm{LSD}=$ Least Significant Difference, $\mathrm{CV}=$ Coefficient of Variation

spike (3.35 g) was obtained with the application of Rondu, as well as, Lintor (3.33 g), Broad way star (3.23 g) and Dimo up (3.18g) (Table 4). While, the minimum grain weight per spike was recorded by weedy check $(1.74 \mathrm{~g})$. The highest weight of grains/spikelet (150.4 mg) was obtained by applying Bromoplus, which was statistically at par with Dolphic (146.6 mg) and Lintor (146.4 mg). This effect may be due to a lower of competition between weeds and wheat plants as a result of weed control, increase the rate of photosynthesis and the accumulation of dry matter in the grains, as well as increased grains weight. The lower grains weight / spikelet was recorded in weedy check (14.5 mg). These results are in concord with the findings of Fayed et al. (1998) and Hussain et al. (2003), who registered that a similar increase in these yield components in their weed control experiments.

Data presented in Fig. 1 and 2 showed the effect of weed control treatments on some yield attributes, i.e.- spike length, number of spikelets/spike, number of grains/spike and number of grains/ spikelet. Dolphik and Aldoal, showed the highest increase in spike length $(11 \mathrm{~cm})$, while the rest of herbicides and hand pulling produced spike length around (8-10 $\mathrm{cm})$ compared to weedy check $(7 \mathrm{~cm})$ (Fig.1). Shahid (1994) reported that herbicides application did not affect significantly reduction in wheat spike length. Data presented in Fig. 2 showed that increased number of spikelets and grains per spike were recorded with the herbicides Lintor, Dolphik, Dimo up and Moar. This increase may be due to increasing the number of fertile flowers in each spikelet.

On the other hand, number of grains per spikelet is an important parameter in wheat yield (Fig. 2). The highest number of grains/spike was recorded with Lintor, Dimo up, Fluromix, but did not differ significantly with treatments Dolphik, Rowndo, Gastin, Moar, Bromoplus, Hoeing and Braod way star, compared to the rest of broadleaved weed control treatments and weedy check, which recorded the lower number of grains/spike (Fig. 2). Herbicides performed better in order to effective weed control and maximum utilization of environmental resources for growth and development. These data agreed with those reported by Fayed (1992), Nassar (1998) and Gupta (2004). 


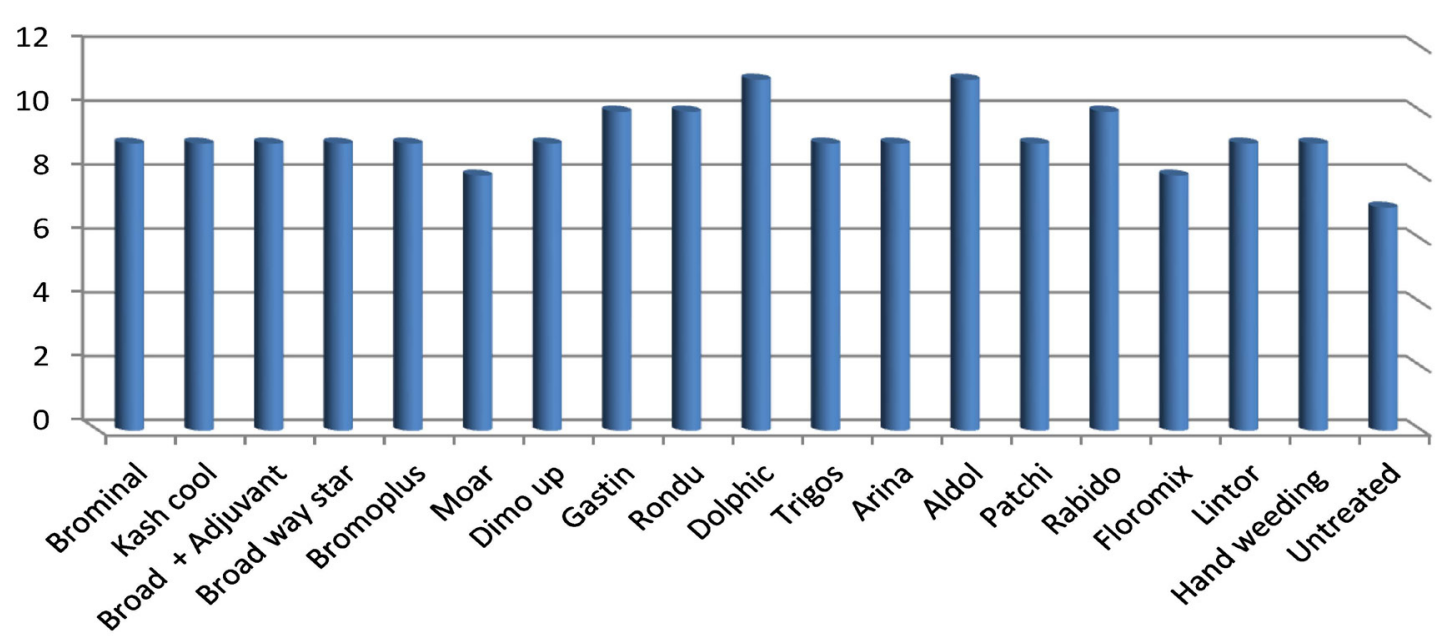

Fig. 1. Effect of weed control treatments on wheat spike length $(\mathrm{cm})$.

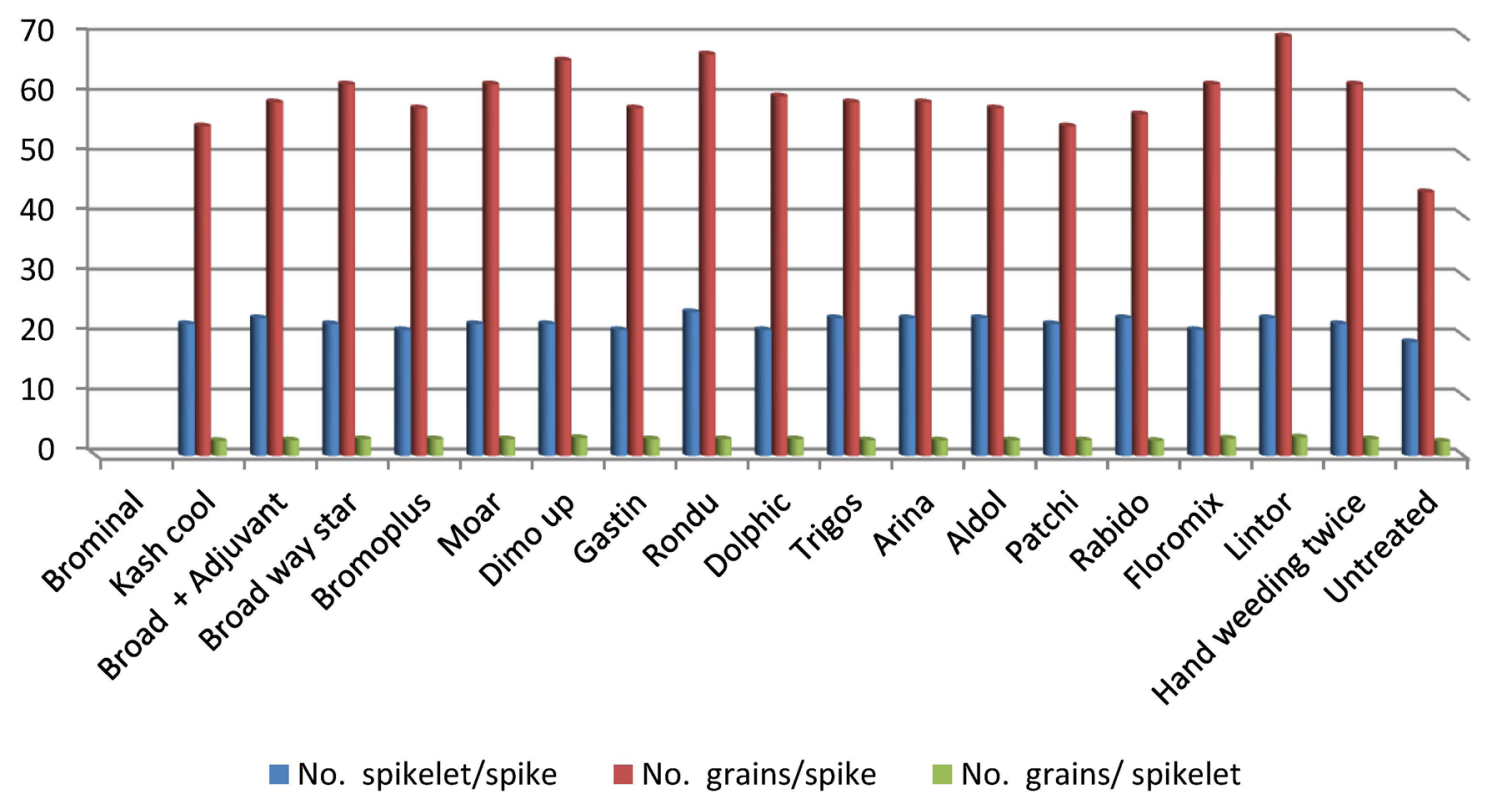

Fig. 2. Effect of weed control treatments on spikelet/splke, no. grains/spiklet and no. grains / spike.

Data presented in Table 5 showed that wheat 1000-grain weight, grain yield/ha, straw yield/ ha and harvest index were significantly affected by all treatments. The maximum weight of 1000-grains $(56.62 \mathrm{~g})$ was obtained by applying Brominal (Table 5), which was statistically at par with Broad way star, Gastin, Dolphic and Arina. Whereas, the lowest number of 1000-grain weight was recorded in weedy check (42.76 g). Brominal herbicide record preference in the 1000- grain weight due to increased weed control resulting in increased net photosynthesis and dry matter accumulation in the grain. Similar findings were obtained by Fayed (1992), Khalil et al. (1993), Metwally et al. (1999) and Gupta (2004).
The highest value of grain yield (14.191 t/ha) was obtained when the herbicide Aldol was used (Table 5), followed by Arina (13.692 t/ha), which was statistically at par with Bromoplus and Gastin (12.399 t/ha). Rondu was statistically at par with Dolphic. Weedy check gave significantly the lowest (7.782 t/ha) grain yield. Also, the grain yield increased by weed control treatments due to increase number of spikes $/ \mathrm{m}^{2}$, number of grains/spike, grain weight/spike and 1000-grain weight. Similar findings were reported by Fenni et al. (2001), Turk \&Tawaha (2003), Nassar (2003), Deep et al. (2005), Zand et al. (2007) and Khan et al. (2008). They reported that the increase in grain yield was due to highest values obtained those from yield components by the application of 
TABLE 5. Seed index, grain yield $t / h a$, straw yield $t / h a$ and harvest index as affected by some weed herbicides for combined data across seasons.

\begin{tabular}{|l|l|l|r|r|l|}
\hline Treatments & Rate/ ha & $\begin{array}{l}\text { Seed } \\
\text { index }\end{array}$ & Grain yield & Straw yield & $\begin{array}{l}\text { Harvest } \\
\text { index \% }\end{array}$ \\
\hline Brominal & $2.38 \mathrm{~L}$ & 56.62 & 10.305 & 24.725 & 29.71 \\
\hline Kash cool & $19.04 \mathrm{~g}$ & 51.00 & 10.995 & 22.705 & 32.86 \\
\hline $\begin{array}{l}\text { Broad way star }+ \\
\text { Adjuvant }\end{array}$ & $214.2 \mathrm{~g}+476 \mathrm{~cm}^{3}$ & 49.34 & 8.092 & 14.280 & 36.29 \\
\hline Broad way star & $214.2 \mathrm{~g}$ & 55.93 & 10.614 & 14.894 & 41.95 \\
\hline Bromoplus & $2.38 \mathrm{~L}$ & 51.28 & 13.692 & 24.297 & 36.11 \\
\hline Moar & $238 \mathrm{~g}$ & 51.17 & 7.694 & 19.089 & 29.13 \\
\hline Dimo up & $595 \mathrm{~cm}^{3}$ & 52.46 & 11.495 & 28.867 & 28.5 \\
\hline Gastin & $83.2 \mathrm{~g}$ & 55.07 & 12.399 & 22.467 & 37.94 \\
\hline Rondu & $1428 \mathrm{~g}$ & 46.77 & 13.097 & 27.303 & 32.44 \\
\hline Dolphic & $1785 \mathrm{~cm}^{3}$ & 55.72 & 13.297 & 24.090 & 35.61 \\
\hline Trigos & $595 \mathrm{~cm}^{3}$ & 47.17 & 11.495 & 21.558 & 34.92 \\
\hline Arina & $1190 \mathrm{~cm}^{3}$ & 55.35 & 13.692 & 22.598 & 37.78 \\
\hline Aldol & $285.6 \mathrm{~g}$ & 46.45 & 14.191 & 28.600 & 33.20 \\
\hline Patchi & $200 \mathrm{~g}$ & 52.31 & 11.797 & 23.957 & 33.46 \\
\hline Rabido & $2.38 \mathrm{~L}$ & 46.91 & 11.090 & 19.558 & 36.21 \\
\hline Floromix & $1547 \mathrm{~cm}^{3}$ & 44.39 & 11.995 & 29.069 & 29.41 \\
\hline Lintor & $142.8 \mathrm{~g}$ & 47.11 & 8.901 & 42.966 & 19.31 \\
\hline Hand weeding twice & & 49.13 & 11.804 & 26.913 & 30.34 \\
\hline Untreated & 42.76 & 7.782 & 18.078 & 30.22 \\
\hline LSD 0.05 & 1.29 & 2.137 & 6.802 & 6.64 \\
\hline CV\% & 2.23 & 39.174 & 58.619 & 17.52 \\
\hline & & & & \\
\hline
\end{tabular}

herbicides in treatments. Hossain et al. (2009) found that wheat yield was gradually decreased with the increase of weed densities. This higher yield under weed control might be due to the decrease on weedcrop competition resulting in higher absorption of nutrients and sufficient interception of sunlight as well as air circulation.

Results showed that the highest straw yield / ha was recorded with Lintor (42.966 t/ha) and in the second hand Aldoal, Floromix, then Dimo up, Gastin and hand pulling. The minimum straw yield produced was recorded with Broadway star+ Adjuvant (14.280 t/ha). Although, weedy check produced straw yield better than Broadway star. The increases in straw yield may be due to minimizing the weed-wheat competition and giving wheat plants the more space without weeds to grew and teller. The results agreed with those obtained by Metwally et al. (1999).

Data concerned with the effect of broadleaved weed control treatments on harvest index are expressed in Table 5. Most herbicide treatments increased harvest index \%. Herbicides Broadway star, Gastin, Arina, were significantly the best in increasing in harvest index compared to all other treatments. While, Brominal, Moar, Dimo-up, Florumix and Lintor decreased harvest index. These outcomes agree with the findings of Fayed et al (1998), and Hussain et al. (2003) who registered a comparable increase in yield components in their weed control trials.

\section{CONCLUSION}

The most important results are: the highest weed control percent more than $90 \%$ were recorded with nine herbicides Rowndo, Dolphic, Trigous, Arina, Rapido, Gastin, Florumix, Cash cool and Broad way star plus adjuvant. These treatments decreased the fresh weight per $\mathrm{m}^{2}$ of broad leaved weeds. For wheat maximum number of spikes/ $\mathrm{m}^{2}$ (578) was obtained with the application of Aldoal, as well as, hand pulling (547), Rowndo 
(524) and Bromoplus (507). While, minimum number of spikes per $\mathrm{m}^{2}$ was recorded with Broad way star with adjuvant (352) and weedy check recorded 414 spikes per $\mathrm{m}^{2}$. The maximum grain weight per spike (3.35 g) was obtained with the application of Rondu, as well as, Lintor (3.33 g), Broad way star (3.23 g) and Dimo up (3.18 g). While, minimum grain weight/spike was recorded by weedy check $(1.74 \mathrm{~g})$. The higher number of grains/spike was obtained with Lintor, Dimo up, Fluromix. The highest 1000-grain weight (56.62 g) was gained by adding Brominal, which was statistically at par with Broad way star, Gastin, Dolphic and Arina, while the lower value of 1000 -grain weight was registered in weedy check $(42.76 \mathrm{~g})$. The maximum grain yield (14.191 t/ ha) was achieved by application of Aldol (Table 5), followed by Arina (13.692 t/ha), which was statistically at par with Bromoplus. Rondu was statistically at par with Dolphic. Weedy check significantly gave the lowest $(7.782 \mathrm{t} / \mathrm{ha})$ grain yield. The highest straw yield /ha was recorded with Lintor (42.966 t/ha) and in the second hand Aldoal, Floromix, then Dimo up, Gastin and hand pulling. The lowest straw yield produced was recorded with Broadway star+ Adjuvant (14288 t/ha). Herbicides Broadway star, Gastin, Arina, significantly increased harvest index compared to all treatments. The results showed that all herbicides increased wheat yield, yield components and reduced weed density number of weeds per square meter. Broadleaved weed control treatments increase control efficacy compared to weedy check.

\section{REFERENCES}

Ali, E.A. and Shams El-Din, G.M. (1997) Effect of pre and post-emergence application of some herbicides on wheat yield and associated weeds. Egypt. J. Appl. Sci. 12 (4), 162 - 171.

Atalla, S.I., Abd El-Hamid, M.M. and El-Mashad, L.A. (1998) Effect of some weed control treatments on weeds and yield of three wheat cultivares. J. Agric. Sci. Mansoura, Univ. 23 (8), 3583 - 3590.

Barhoma, M.A., Ibrahim, H.M. and Moshtohry, M.R. (1996) Influence of certain herbicides in controlling broad-leaved and grassy weeds in wheat fields. Ann. Agric. Sci., Moshtohor, 34(2), 465-472.

Deep, K., Angiras, N. N., Singh, Y. and Rana, S. S. (2005) Influence of integrated weed management practices on weed competition for nutrients in wheat. Indian J. Agric. Res. 39(2),110-115.

FAO (2016) Food and Agriculture Organization of the United Nations. Views country briefs. http://faostat.fao. org/site/567/default.aspx\#ancor

Fayed, E.H.M. (1992) Effect of sowing methods, weed control methods and nitrogen fertilization on weeds and yield of wheat. Egypt. J. Appl. Sci. 7 (7), 908 - 921.

Fayed, E.H.M., Leilan, A.A. and Bassiouny, A.H. (1993) Effect of chemical weed control and nitrogen fertilization on weeds occurrence and yield of wheat. $J$. Agric. Sci. Mansoura Univ. 18 (1), $1-10$.

Fayed, T.B., Sabry, S. and Aboul-Ela, S. (1998) Effect of wild oat herbicides on weed density, wheat grain, and yield components. Annals Agri. Sci. Cairo, 43(1), 173-188.

Fenni, M., Shakir, A.N. and Maillet, J. (2002) Comparative efficiency of most widely used herbicides in durum wheat (Triticum aestivum) in Algeria. J. Plant Protection, 1, 55-58.

Fenni, M., Shakir, A. N. and Maillet, J. (2001) Comparative efficacy of five herbicides on winter cereal weeds in semi-arid region of Algeria. Proc. 53 $3^{\text {rd }}$ Int. Symposium on Crop Prot., Gent, Belgium, pp. 791795.

Gomez, K.A. and Gomez, A.A. (1984) "Statistical Procedures for Agricultural Research"(2 ed.). John Wiley and Sons, NewYork, 680p.

Gupta, O.P. (2004) "Modern Weed Management" $\left(2^{\text {nd }}\right.$ ed.). pp. 18-23, Agrobios Jodhpur, India.

Hassanein, E.E., Ibrahim, M.H., Kholosy, S.A., Al-Marasafy, T.H. and Aboelenin, A.R. (2000) Manual of weed identification and control in wheat. Weed control Research Section in Collaboration with the European Union. The international Center for Agriculture Research in the Dry Areas (ICARDA), 30105, Cairo, Egypt, pp. 1-185.

Hossain, M. I., Barma, N.C.D., Islam, A.T. M. R., Uddin, M.Z. and Rahman, M.M. (2009) Eloped herbicides on the growth and yield of wheat. Int. J. Sustain. Crop Prod. 4(1), 1-4.

Hussain, M. B. K., Tariq, M. and Hanif, S. (2003) Spectrum of activity of different weed management practices on growth and yield of wheat (Triticum aestivum L.). International J. Agric. Biology, 5 (2),166168.

Javaid, A., Bajwa, R., Rabbani, N. and Anjum, T. (2007) Comparative tolerance of six rice (Oryza sativa L.) genotypes to allelopathy of purple nutsedge (Cyperus rotundus L.). Allelopathy J.20 (1), 157-166.

Jitendra, P., Verma, A.K. and Pandey, J. (2002) Effect of atrazine, metriibuzin, sulfosulfuron and tralkoxydim on weeds and yield of wheat (Triticum aestivum). Indian, J. Agron. 47(1), $72-76$.

Khalil, M. F., Hassan, G., Ahmad, G., Anwar, S. and Khan, S. (2013) Comparative efficacy of herbicides on yield and yield components of wheat (Triticum aestivum L.). ARPN J. Agric. Biol. Sci. 8(1), 76-80 
Khalil, S.K., Khan, A.Z., Paigham, S., Baloch, A.R. and Malik, M.F. (2000) Herbicides and row spacing effect on leaf characteristics and grains per spike of wheat. Sarhad J. Agric. 16(1), 13-17.

Khalil, O.H.S., Gomaa, A.S.A., Abo Elenein, R.A. and El-Kalla, S.E. (1993) Effect of seeding rate, nitrogen fertilization and method of seeding on performance of wheat variety Mexipak. Agric. Res. Rev. (55),1-11.

Khan, B. M., Muhammad, S., Zahid, H., Bakhtiar, G. and Haroon, R. (2008) Study of various herbicide for weed control in wheat under irrigated condition. Pak. J. Weed Sci. Res. 14(1-2), 1-8.

Malik, R. S., Balyan, R. S., Malik, R. K. and Pahwa, S. K. (2004) Grass weed control in wheat by clodinafop applied with and without surfactant. Indian $J$. Weed Sci. 36(1), 8-11.

Marwat, K.B., Hussain, Z., Saeed, M., Gul, B. and Noor, S. (2005) Chemical weed management in wheat at higher altitudes. Pak.J. Weed Sci. Res. 11(3), 102-107.

Metwally, G.M., El-Desoki, E.R. and Abdallah, A.E. (1999) Effect o

f some post-emergence herbicides on wheat yield and associated weeds. J. Agric. Sci. Mansoura Univ.24(12), $7215-7224$.

Muhammad, A. S., Muhammad, A. N., Ghulam, M. N. and Furrkh, I. (2012) Comparative efficacy of different post-emergence herbicides in wheat (Triticum aestivum L.). Pak. J. Agri. Sci. 49(1), 27-34.

Nassar, A.N.M. (1998) Effect of sowing methods and weed control on wheat crop under Upper Egypt conditions. Ph. D. Thesis, Fac. Agric. Al-Azhar Univ. Cairo, Egypt.

Nassar, A.N.M. (2003) Performance of some wheat varieties with clodinafop-propargyl herbicide on wild oat control and wheat productivity. Egypt. J. Appl. Sci. 18 (8B),481-496.

Raza, M., Muhammad, F., Sakhi, M. and Umer, A. A. S. (2015) Efficacy of different commercially available weedicides on wheat Triticum aestivum in Rawalpindi Pakistan. Int. J. Agri. \& Agri. R. 7(2), 205-209.

Shaban, S.h.A. and El-Deek, M.H. (1986) Weed control in wheat. Proc. $2^{\text {nd }}$ Conf. Agron. Alex., Egypt. 1, pp.517-529.

Shah, M. A., Sana, U. C. and Muhammad, A. A. (2004) Evaluation of some herbicides for the control of weeds in wheat crop. Pak. J. Life Soc. Sci. 2(1), 24-27.

Shahid (1994) Screening of different weed management practices for controlling weeds in wheat crop M.Sc. Thesis, Faculty of Agriculture, Gomal University, Pakistan. pp.102-108.

Shahram, L., Pegah, P. and Modhej, A. (2011) Study the effects of nitrogen levels and wild oat (Avena ludoviciana L.) densities on grain yield and agronomic nitrogen efficiency of wheat (Triticum aestivum L.). Advances in Environmental Biology, 5(8), 2445-2450.

Täckholm, V. (1974) "Students' Flora of Egypt". $2^{\text {nd }}$ ed. Cairo University, Cairo. pp. 888.

Tesfay, A., Sharma, J.J. and Zewdie, K (2014) Effect of weed control methods on weeds and wheat (Triticum aestivum L.) yield. World J. Agric. Res. 2 (3), 124-128.

Turk, M.A. and Tawaha, A.M. (2003) Weed control in cereals in Jordan. Crop Production, 22(2), 239-246.

Weed Sci. Soc. of Am. http://wssa.net/wssa/weed/ weed-identification/

Zand, E., Baghestani, M.A., Soufizadeh, S., Eskandari, A., PourAzar, R. and Veysi, M. (2007) Evaluation of some newly registered herbicides for weed control in wheat (Triticum aestivum L.) in Iran. Crop Protec. 26,1349-1358. 


\section{مقاومة الحشائش عريضة الاوراق في القمح باستخدام بعض المبيدات الحدثية بين الانبات فى}

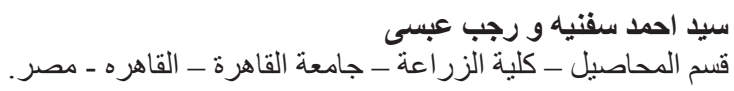

تسبب الحشائش عريضة الاوراق نقص شديد فى محصول القمح في مصر ، اجريت تجرتين حقليتن خلال

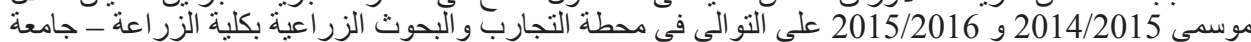

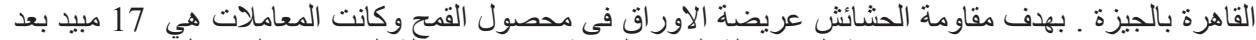

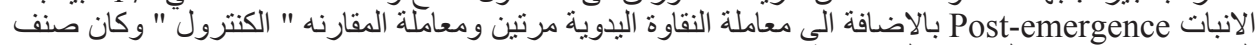

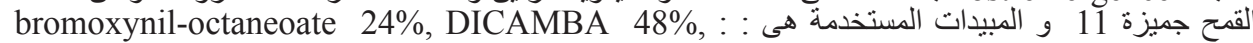
Tribenuron-Methyl $16 \%$ + Carfentrazone-Ethyl 12\%, MCPA-sodium 20\%+ Bromixanil $20 \%$, Florasulam $0.25 \%+$ Mesosulfuron-Methyl 0.75\%, MCPA-sodium 36\%+ Florasulam $1 \%$, Florasulam $05 \%$ + Clodinafop-propagyl 6.5\%, Tribenuron-Methyl $2.7 \%+$ Fluroxypyr $13.7 \%$, Tribenuron-Methyl 5\%+ Clodinafop-propagyl 10\%, bromoxynil-octanoate $25 \%$

, Triasulfuron 4.1\% + Dicamba $65.9 \%$, Tribenuron-Methyl 8\%+ Fenoxaprop-pEthyl $45 \%+$ Thifensulfuron-Methyl 12\%, Bromoxynil octaneoate, Florasulam $1.42 \%+$ Pyroxsulam 7.08\%,Florasulam 1.42\%+ Pyroxsulam 7.08\%+ Ecosurf, Tribenuron-Methyl

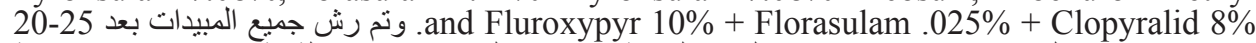

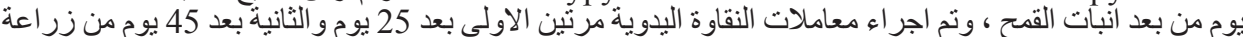

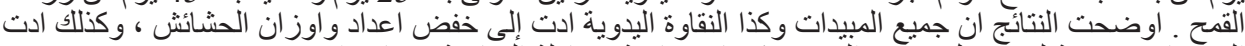

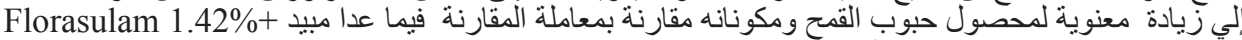
Triasulfuron 4.1\% + Dicamba و الاسم التجاري برو اد و اي ستار . وكان مبيد 65.9 و $6.08 \%$ \% و الاسم التجاري لينتور الاعلي فى عدد الحبوب في السنبلة وكذللك عدد السنابل للنبات الو احد و ايضا محصول

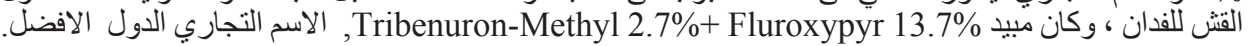

